\title{
Effects on drying characteristics of osmotic dehydrated pineapple (Ananas comosus) slices using different drying temperatures
}

\author{
Vipul Chaudhary*, Vivak Kumar, Sunil, Suresh Chandra, Samsher and B.R. Singh \\ Department of Agricultural Engineering, Sardar Vallabhbhai Patel University of Agriculture and \\ Technology, Meerut-250110 (U.P.)
}

* E-mail: vipulchaudhary.in@gmail.com

\begin{abstract}
Drying is an essential process in the preservation of agricultural products. Various drying methods are employed to dry different agricultural products. Each method has its own advantages and limitations. Choosing the right drying system is thus important in the process of drying agricultural products. An experimental study was performed to determine the drying characteristics of pineapple slices subjected to drying in hot air oven at $50^{\circ} \mathrm{C}, 60^{\circ} \mathrm{C}$ and $70^{\circ} \mathrm{C}$ with osmotic treatment indicated that $\mathrm{T}_{0}$ (Control), $\mathrm{T}_{1}\left(50^{\circ} \mathrm{Brix}\right)$ and $\mathrm{T}_{2}\left(60^{\circ} \mathrm{Brix}\right)$. The entire drying process took place in the falling rate period. Drying curves were constructed using non-dimensional moisture ratio (MR) and time. Drying is the most widely used and a primary method for preservation. The result indicated that the hot air oven at $70^{\circ} \mathrm{C}$ was found better drying characteristics compare to other drying temperatures.
\end{abstract}

Keywords: Pineapple slices, osmotic dehydration, hot air oven, drying rate, moisture content.

Paper cited: Chaudhary, V., Kumar, V., Sunil; Chandra, S., Samsher and Singh, B.R. (2019). Effects on drying characteristics of osmotic dehydrated pineapple (Ananas comosus) slices using different drying temperatures. South Asian Journal of Food Technology and Environment, 5(1): 778-784.

\section{Introduction}

Hot air drying often degrades the product quality, provides low energy efficiency and lengthy drying time during the falling rate period. It has been reported that hot-air drying of food materials, involving their prolonged exposure to elevated drying temperatures, results in substantial deterioration of such quality attributes as color, nutrient concentration, flavor and texture (John et al., 2017). In the process, more water than solute is usually removed due to the deferential permeability of cellular membranes (Ramallo and Mascheroni, 2012). Drying is a technique of conservation that consists of the elimination of large amount of water present in a food by the application of heat under controlled conditions, with the objective to diminish the chemical, enzymatic and microbiological activities that are responsible for the deterioration of foods (Barnabas et al.,
2010). Water removal is the main task while preserving food (Lenart, 1996) reducing the moisture contents to a level, which allows safe storage over an extended period of time. Dried foods also present low storage and transportation cost when compared to the fresh ones (Okos et al., 1992). The increase in drying rate and decrease of heat transfer provide energy saving of microwave drying. Drying is perhaps the oldest, most common and most diverse of chemical engineering unit operations in the preservation of agricultural food materials or products (Dincer, 1996). It is the process moisture (water) removal from substances due to simultaneous heat and mass transfer (Waewsak et al., 2006). The mechanism of drying process consist of the transport of (mass) moisture from the interior of the solid to the surface, the vaporization of liquid at the surface (diffusion) and the transport of the vapor into gas phase (Seyed et al., 1999). The drying operation 
reduces the moisture content of solids to a condition favorable for safe storage without deteriorations. (Kumar et al., 2019).

Drying is a very simple and old method to preserve fruits. Drying is one of the most popular drying methods with a low-cost application. However, it has disadvantages. The process is time consuming (Nawirska et al., 2009) and may result in a significant change in the quality in the dried products (Qing-Guo et al., 2006). Hot air oven drying has been on the rise in popularity as an alternative method. In principal, electromagnetic energy is directly converted to kinetic energy in the water molecules, and the product itself produces the heat (Motevali et al., 2011). The high drying rate, reduced process time and lower energy requirement of hot air oven drying (Nazmi et al., 2018).

Vegetables and fruits are indispensable part of human diet and can be regarded as the fuel for physiological processes. About 25-30\% of total produce is being wasted during handling from point of production to consumer's plates. This wastage can be effectively reduced by applying appropriate method of processing and preservation. In this regard some of the vegetables have been traditionally processed by drying to extend their storage life well beyond few weeks and make it available in off season (Wankhade et al., 2012)

\section{Materials and Methods}

Raw material: The local variety of fresh pineapple was purchased from the Meerut market and was used in the experiments. The cleaned product was then weighed and $300 \mathrm{~g}$ samples were made for each methods of drying.

Osmotic treatments: Fresh, good quality of pineapple were washed to remove soil particles attached to the surface. Then sorted cleaned pineapple was cut into $4.5 \mathrm{~mm}$ thickness. The sliced pineapple was subjected to osmotic treatment. In this, the pineapple slices were dipped in osmotic solution having sugar concentration ranging from 50 to $60{ }^{\circ} \mathrm{Brix}$ at $45^{\circ} \mathrm{C}$ temperature for 180 minute. Then slices were removed from the solution and the surface moisture was removed by blotting paper than after slices were subjected to drying in Hot air oven at $50^{\circ} \mathrm{C}, 60^{\circ} \mathrm{C}$ and $70^{\circ} \mathrm{C}$. After drying slices.

Drying procedure: The experimental set up used for determining the influence of drying temperature on drying behavior of pineapple slices. The slices were then weighed exactly $300 \mathrm{~g}$ for each treatment. These were kept for drying in three replications.

Hot air oven isan adjustable aluminum tray type for food products drying. It was carried by drying the samples at $50^{\circ} \mathrm{C}, 60^{\circ} \mathrm{C}$ and $70^{\circ} \mathrm{C}$ air temperatures. Pineapple slices sample weighing $300 \mathrm{~g}$ was taken and spread uniformly over the perforated bottom trays in single layer. Drying air temperature was adjusted to the desired level using the thermostat. During drying operation, weight of the sample was taken at every $30 \mathrm{~min}$ interval for rest of drying period. All the measured observations were recorded for further calculations. Drying was stopped when the drying mass reached the required moisture content. The dried product was cooled to normal temperature in a desiccators containing silica gel and then packed in polyethylene bags, which were then heat-sealed and stored at room temperature. The experiments were repeated twice and the average of the moisture ratio at each value was used to draw the drying curves.

Drying time and curves: During drying of pineapple slices, samples were weighed at the specified intervals mentioned above for determining moisture content. The drying curves were drawn for all moisture content $(\% \mathrm{db})$ was plotted against time of drying. The total time required for complete drying was also recorded in each case. The curves between drying rate and average moisture content $(\% \mathrm{db})$ and between drying rate $(\mathrm{g} / \mathrm{min})$ and drying time $(\mathrm{h})$ were also plotted.

Moisture content: Moisture content of the sample was determined by standard air oven method (Ranganna, 1995). Five samples each weighing $15 \mathrm{~g}$ were kept in the hot air oven at $103^{\circ} \mathrm{C}$ for 6 hours and the weight of the samples was recorded at every one-hour interval till constant weight was reached. The loss in weight 
was determined and moisture content was calculated using the following equation:

$$
\begin{aligned}
\text { M C\% (w. b) }= & \frac{(\text { initial weight }- \text { final weight })}{\text { initial weight }} \times 100 \\
\text { M C\% (d. b) }= & \frac{(\text { initial weight }- \text { final weight })}{\text { final weight }} \\
& \times 100
\end{aligned}
$$

Drying rate: Drying rate will be calculated as weight of water removed per unit time per unit weight of the bone dry matter.

$$
\mathrm{R}=\frac{\mathrm{Mi}-\mathrm{Md}}{\mathrm{T}}
$$

Where, $\mathrm{R}$ is the Drying rate $(\mathrm{g} / \mathrm{min})$ and $\mathrm{T}$ is the Time taken (h), $\mathrm{M}_{\mathrm{i}}$ is the mass of sample before drying and $\mathrm{M}_{\mathrm{d}}$ is the mass of sample after drying.

\section{Results and Discussion}

\section{Variation of Moisture Content with Time}

Fresh Pineapple of good and uniform quality was obtained from a local market (Modipuram) Meerut. The initial moisture content prior to drying was observed $566.6 \%$ (db.). The variation in moisture content with drying time is shown in Fig. 1 to 3 at different temperatures and different treatments. It was observed that pineapple slices took 300, 330, and 420 minutes to reduce the moisture content at constant level for all samples in hot air oven drying. The pineapple slices were dried at $50^{\circ} \mathrm{C}$, $60^{\circ} \mathrm{C}$, and $70^{\circ} \mathrm{C}$ for intervals of $30 \mathrm{~min}$ in a hot air oven to achieve the final moisture content. All samples took $420 \mathrm{~min}$ to attain final moisture content at $50^{\circ} \mathrm{C}$, the final moisture content were found $8.88 \%, 55.55 \%$, and $77.77 \%$ for controlled, $50^{\circ} \mathrm{B}$ and $60^{\circ} \mathrm{B}$ samples respectively The moisture content was found highest in $60^{\circ} \mathrm{B}$ as compared to control and $50^{\circ} \mathrm{B}$ sample at $50^{\circ} \mathrm{C}$. It was observed that all samples took $360 \mathrm{~min}$ to attain final moisture content $6.66 \%, 51.11 \%$, and $64.44 \%$ for controlled, $50^{\circ} \mathrm{B}$ and $60^{\circ} \mathrm{B}$ samples respectively The moisture content was found highest in $60^{\circ} \mathrm{B}$ as compared to control and $50^{\circ} \mathrm{B}$ sample at $60^{\circ} \mathrm{C}$. It was observed that all samples took $180 \mathrm{~min}$ to attain final moisture content $4.44 \%, 48.88 \%$, and $62.22 \%$ for controlled, $50^{\circ} \mathrm{B}$ and $60^{\circ} \mathrm{B}$ samples respectively The moisture content was found highest in $60^{\circ} \mathrm{B}$ as compared to control and $50^{\circ} \mathrm{B}$ sample at $70^{\circ} \mathrm{C}$. The drying times at $50^{\circ} \mathrm{C}, 60^{\circ} \mathrm{C}$, and $70^{\circ} \mathrm{C}$ were observed as $420,360,300 \mathrm{~min}$ respectively for all samples in hot air oven. In hot air oven drying with increasing temperature drying time decreased (Upadhyaya et al., 2012). The results for drying methods showed that control caused shorter drying time relative to osmotic dehydrated $\left(50^{\circ} \mathrm{Brix}\right.$ and $\left.60^{\circ} \mathrm{Brix}\right)$ samples.

\section{Variation of drying rate with Time}

The drying rate was calculated by dividing difference of two consecutive. The result of hot air oven drying experiments showed that increasing of hot air temperature increased drying rate. It was found that change in drying rate ( $\mathrm{g}$ water / $\mathrm{g}$ dry matter-min) with moisture content ( $\mathrm{g}$ water / $\mathrm{g}$ dry matter) for controlled (To), $50^{\circ} \mathrm{B}\left(\mathrm{T}_{1}\right)$ and $60^{\circ} \mathrm{B}\left(\mathrm{T}_{2}\right)$ pineapple slices at temperature $50^{\circ} \mathrm{C}, 60^{\circ} \mathrm{C}$ and $70^{\circ} \mathrm{C}$ has been presented controlled in fig 4 to 6 . It was observed that drying, rate was higher in the initial periods of drying and subsequently it reduced with decrease in moisture content. Drying rates by drying pineapple slices at $50^{\circ} \mathrm{C}$ were found $0.71,0.60$ and 1.69 for $50^{\circ} \mathrm{B}, 60^{\circ} \mathrm{B}$, and controlled sample respectively. The mean drying rates during drying of pineapple slices were found $0.92,0.81$ and 1.86 for $50^{\circ} \mathrm{B}, 60^{\circ} \mathrm{B}$, and controlled sample respectively at $60^{\circ} \mathrm{C}$. The drying rates during drying of pineapple slices were found $1.02,0.90$, and 2.0834 for $50^{\circ} \mathrm{B}$, $60^{\circ} \mathrm{B}$, and controlled sample respectively at 70 C. Experimental results of hot air oven drying method showed that drying rate of controlled samples was higher than osmotic dehydrated samples. On comparing the method of drying, it can be visualized that the highest drying rate was achieved with $\left(\mathrm{T}_{0}\right)$ control at $70^{\circ} \mathrm{C}$ hot air oven and $50^{\circ} \mathrm{Brix}\left(\mathrm{T}_{1}\right), 60^{\circ} \mathrm{Brix}\left(\mathrm{T}_{2}\right)$ at $50^{\circ} \mathrm{C}$ and $60^{\circ} \mathrm{C}$ least in drying rate. 

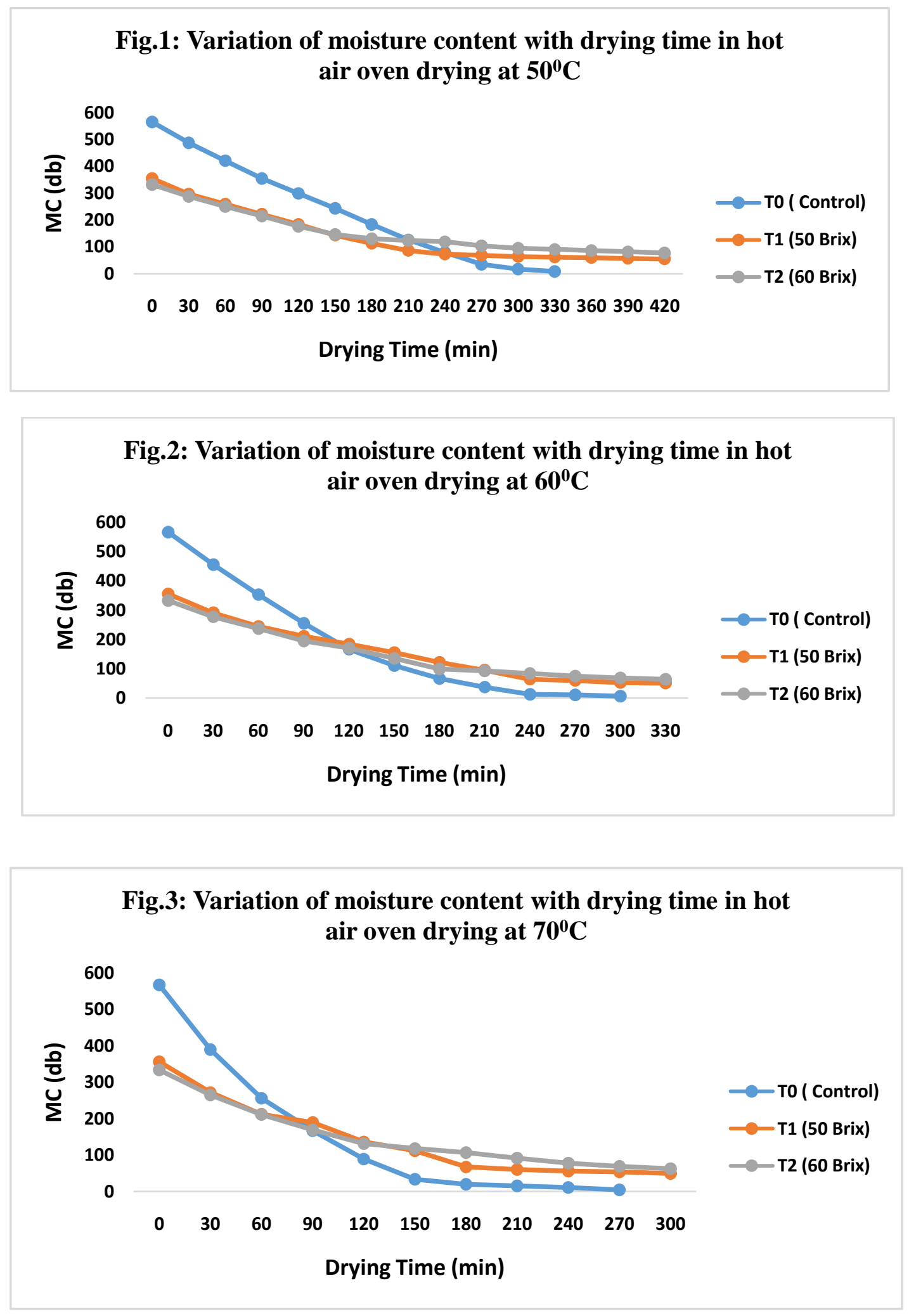

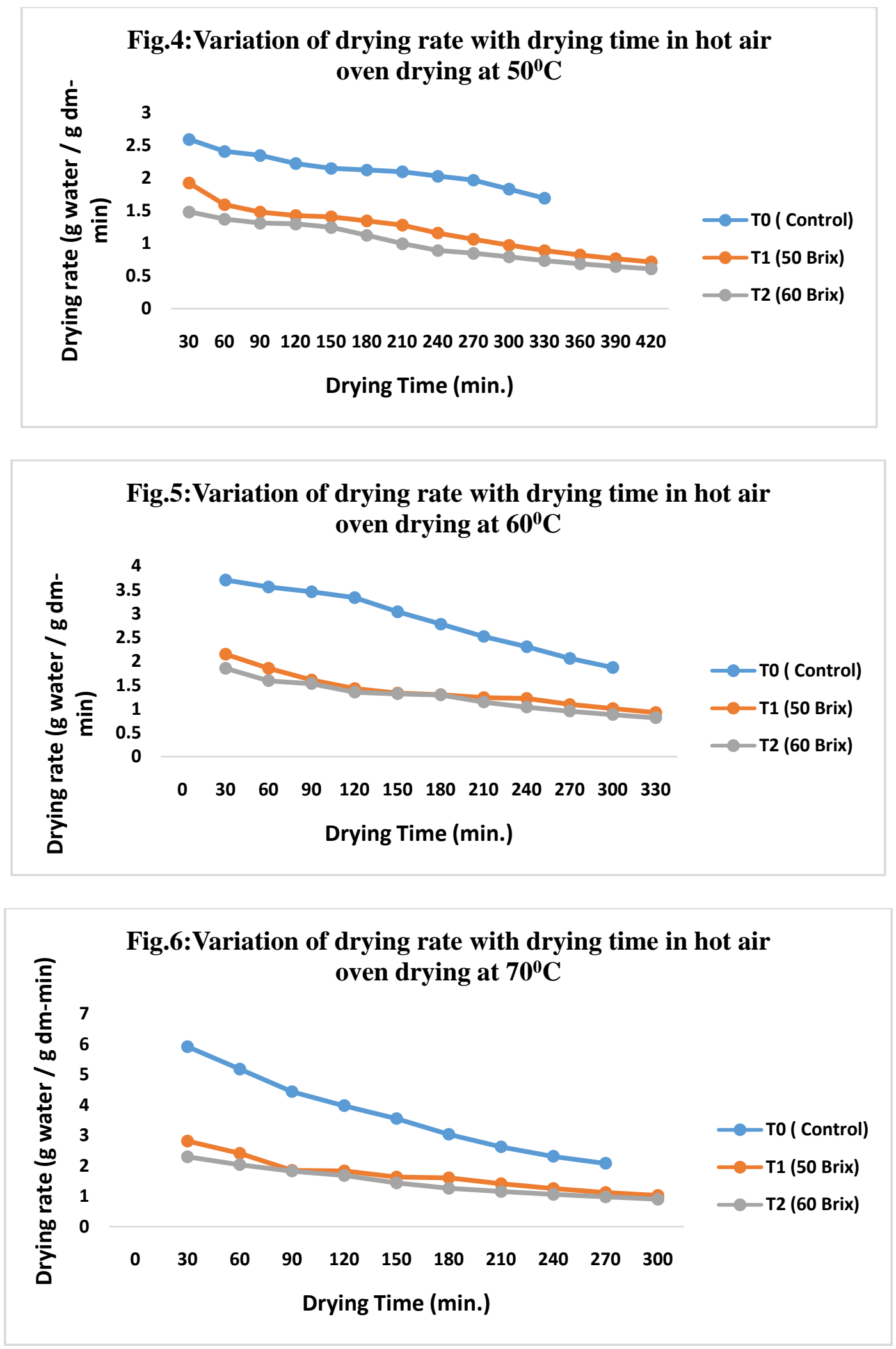


\section{Conclusion}

In conclusion, the drying curves were affected by the drying air temperature. Drying rate was observed from the curves that the drying rate was higher in the initial period of drying and subsequently it was reduced with decrease in moisture content. The drying in falling rate period indicates that internal mass transfer occurred by diffusion. The drying temperature has an essential role in the characterization of drying behavior of pineapple samples. The drying of pineapple slices occurred in the falling rate period and no constant rate period of drying was observed. The $70^{\circ} \mathrm{C}$ drying technique was more efficient than $50^{\circ} \mathrm{C}$ and $60^{\circ} \mathrm{C}$ drying. Highest drying rate was achieved with by hot air oven at $70^{\circ} \mathrm{C}$ and least in the $50^{\circ} \mathrm{C}$ drying. The pineapple slices dried in hot air oven at $70^{\circ} \mathrm{C}$ better results in maintaining. This method is better time saving gives better results obtained during drying process

\section{Acknowledgment}

This work was supported by Department of Agricultural Engineering, Sardar Vallabhbhai Patel University of Agriculture and Technology, Meerut (U.P.)

\section{References}

Barnabas, M., Siores, E. and Lamb, A. (2010). Non-thermal microwave reduction of pathogenic cellular population. International Journal of Food Engineering (6): 1-18

Dincer, I. (1996). Sun drying of sultan grapes, Drying Technology, (14):18271838.

John, C., Domingo, Vera, W.M.D. and Pambid, R.C. (2017). Exploring Oven-drying Technique in Producing Pineapple Powder. Asia Pacific Journal of Multidisciplinary Research, 5(4): 90-96.

Kumar, V., Singh, J., Kumar, R, Sunil and Chaudhary, V. (2019). Effect of Hot Air Oven Drying on the Moisture Kinetics and Drying Rate of Osmo-Dried Papaya (Carica papaya L.) Slices. International Journal of Current Microbiology and Applied Sciences. 8(2): 1945-1951.

Lenart, A. (1996). Osmo-convective drying of fruits and vegetables. Technology and application. Drying Technology, 14: 391413.

Motevali, A., Minaei, S., Khoshtaghaza, M.H. and Amirnejat, H. (2011). Comparison of energy consumption and specific energy requirements of different methods for drying mushroom slices. Energy, 36: 6433-6441.

Nawirska, A., Figiel, A., Kucharska, A.Z., Sokoł-Łetowska, A. and Biesiada, A. (2009). Drying kinetics and quality parameters of pumpkin slices dehydrated using different methods. Journal of Food Engineering, 94: 14-20.

Nazmi, I., Gokcen, I. and Taskin, O. (2018). Impact of different drying methods on the drying kinetics, color, total phenolic content and antioxidant capacity of pineapple. CyTA-Journal of Food, 16(1): 213-221.

Okos, M.R., Narsimham, G., Singh, R.K. and Witnauer, A.C. (1992). Food dehydration. In: D. R. Heldman \& D. B. Lund (Eds.), Handbook of food engineering. New York: Marcel Dekker.

Qing-Guo, H., Min, Z., Mujumdar, A. S., WeiHua, D. and Jin-Cai, S. (2006). Effects of different drying methods on the quality changes of granular edamame. Drying Technology, 24: 1025-1032.

Ramallo, L.A. and Mascheroni, R.H. (2012). Quality evaluation of pineapple fruit during drying process. Food and bio products processing, 90: 275-283. doi:10.1016/j.fbp.2011.06.001

Ranganna, S. (1995). Handbook of analysis and quality control for fruits and vegetable products. $2^{\text {nd }}$ ed, Tata McGraw Hill Publishing Company Limited, New Delhi, India.

Seyed, J.Y., Moreira, R.G. and Yamseangsung, R. (1999). Superheated steam impingement drying of tortilla chip. Drying Technology, 17: 191- 213.

Upadhyaya, A.K., Gupta, B., Garg, S., Singh, M. and Pandey, M. (2012). Study of Moisture Depletion Pattern of Spinach in Hot Air Oven. International Journal of Engineering Research and Applications, 2, (4):301-310. 
Waewsak, J., Chindaruksa, S. and Punlek, C. (2006). A mathematical modeling study of hot air drying for some agricultural products. International Journal of Science and Technology, 11:14-20.

Wankhade, P.K., Sapkal, R.S. and Sapkal, V.S. (2012). Drying Characteristics of Okra Slices using Different Drying Methods by Comparative Evaluation. Proceedings of the World Congress on Engineering and Computer Science, 2:978-988.

$\begin{array}{ll}\text { Received } & \text { : March, } 2019 \\ \text { Revised } & : \text { May, 2019 } \\ \text { Published } & \text { : June, 2019 }\end{array}$

